\title{
E-governance Framework to Measure Digital Competence of HEIs in India
}

\begin{abstract}
Neera Chopra
PhD Student at Doctoral School of Public Administration Science in the National University of Public Service, Budapest, Hungary

Doi:10.19044/esj.2019.v15n11p181 URL:http://dx.doi.org/10.19044/esj.2019.v15n11p181

Abstract

Today, Higher Education Institutions are using ICT to provide administration and management services, develop course materials, facilitate communication among students and increase cooperation and research. Information on how most Universities have integrated ICT and to what stage is lacking. Nevertheless, some studies indicate differences in the level of the use of ICT among HEIs. The present study discusses the framework developed by the Joint Research Centre, European Commission that can be applied to assess digital co

mpetency of Higher Education Institutions in India. A questionnaire, based on the above-stated framework has been formulated to assess, analyse and ascertain the status of ICT integration on the 6 parameters - namely Leadership and Governance Practices, Teaching and Learning Practices, Professional Development of the Teaching and Non-Teaching staff, Assessment Practices, Collaboration and Networking; and Infrastructure. The expected result will be of interest to policymakers and academicians in the field of Higher Education in India.
\end{abstract}

Keywords: E-governance, ICT, HEIs, digital technologies.

\section{Introduction}

Indian higher education is undergoing a rapid transformation in terms of access, equity and quality. As the GER (Gross Enrolment Ratio) in Indian higher education is increasing, the government is setting new time-bound targets for achieving 30\% GER (Mukhopadhyay and Parmar 2014). The government of India (2012) noted that India's higher education system is the third largest in the world, after China and the United States. This means that there has been a great massification of students over the last two decades; leaving more strains to University infrastructure, personnel, and many more. 
One of the major challenges of Higher Education Institutions is to conduct all administrative functions in a seamless manner. With a large number of applicants of Tertiary education vying to secure a seat in the desired institution in accordance with their merit, it becomes challenging to conduct the admissions in a fair and transparent manner. Rapid growth in enrolment has made governance a challenging task. E-governance is the solution to enable transparency and eliminating arbitrariness in decision-making.

Singh (2010) quoting Rajshekhar (2002) as cited in Jain and Ramani (2005) defines E-governance as "the application of information and communications technologies (ICTs) in a system of governance, to bring in simple, moral, accountable, responsive, and transparent (SMART) governance" (Singh, 2010: 255). The introduction of e-governance entails streamlining operational processes, transcribing information held by government agencies into electronic form, linking disparate databases, and improving ease of access to services for members of the public (Singh, 2010). The advantages of ICT over conventional systems include greater accessibility, wider multi-communication and faster dissemination of information. Moreover, its automatic record keeping features generally, enable better knowledge management and information sharing. E-governance solution in the educational sector can facilitate the delivery of services to students and faculty like enrolment, examination, result, request for documents and certificates, issuance of admit-cards and I-cards, employment (Srivastava et. al., 2014) transport, library, staff details, and payroll etc. and student fees among various departments in an academic institution. A good example is Lovely Public University in Jalandhar. It has created a Management Information system comprising different modules, namely Admissions, Human Resources, Transportation, Examination, a Question bank, document managing system etc. This has facilitated the delivery of personalized services at the doorstep of students and reduced data duplicity efforts. These multiple benefits help the University save time and cost for services. Similarly, some open universities have led the initiative to embark upon the journey of e-governance, with an equal degree of success and benefits.

The present study has been conducted on an extensive review of literature ranging from 2010-2018 using literature available online, accessed through google scholar, Wiley online and Ebsco, besides the relevant literature published in English language, available at the NUPS and CEU Libraries. The study proposes to adapt and apply the DigCompOrg Framework, specifically designed to evaluate the educational institutions including HEIs to enable them to "self-reflect on their progress in integrating and effectively using digital learning technologies" (Kampylis et. al., 2015: 4 ). A framework is important for HEIs to help them put efforts on the strategic points in order to 
be digitally competent to embrace ICT. The DigCompOrg Framework evaluates the Educational Institutions on six basic parameters, each of which is divided into sub-sections of varying proportions. The assessment is done based on the descriptors, which define in detail each of these sub-sections. The DigCompOrg Framework is described at length in section 6 below.

\section{Significance of the study}

The goal of the survey is to assess the extent to which the HEIs have incorporated ICT in various aspects of administration and management. It will also help the HEIs to examine their level of competence to implement ICT in all its aspects. The questionnaire will also enable the HEIs to compile enough data to allow them to better use ICT and assess the value thus gained. The main outcome will be to determine the factors responsible or not responsible to achieve HEIs engagement with digital technology. So the results can identify the strengths and 1weaknesses of the existing appropriate Equipment, Systems, Processes and People working and improving them in alignment to the University's strategy. To sum up, a digitally-competent educational institution needs capabilities at the top as well as in the rank and file. In other words, "a strong leadership and governance (for vision and top-down strategies) and at the same time, staff and stakeholders, who are individually capable of taking responsibility for self-initiated actions and bottom-up efforts and initiatives." (Kampylis et al., 2013: 6).

\section{E-governance and Digital India}

Despite the successful implementation of many e-Governance projects across the country, e-Governance as a whole has not been able to make the desired impact and fulfil all its objectives (www.Digital India.gov.in). The technological infrastructure and access to ICT tools is a precursor to facilitating e-governance. On $1^{\text {st }}$ July 2015, the flagship programme 'Digital India' was introduced by the Government of India to transform the entire ecosystem of public services through the use of ICT (www.Digital India.gov.in). The vision is to transform India into a digitally empowered economy electronically so that services are provided to the people on their mobile phones, laptops, tablets through high-speed internet (McKinsey Global Institute, 2017 as cited in Vijayan, 2019). It focuses on making government services and administration accessible to every citizen electronically by reducing paperwork. Creating broadband highways across the length and breadth of the country has helped increase internet users. According to a report by McKinsey Global Institute (2017), the number of subscribers has increased from 210 million in 2013 to 270 million in 2015 and 350 million in 2018. The number of users with $3 \mathrm{~GB}$ and $4 \mathrm{~GB}$ broadband increased from 330 million to 750 million thus improving efficiency and faster delivery of information. 
Figure 1.

Annual comparison of E-governance transactions in India

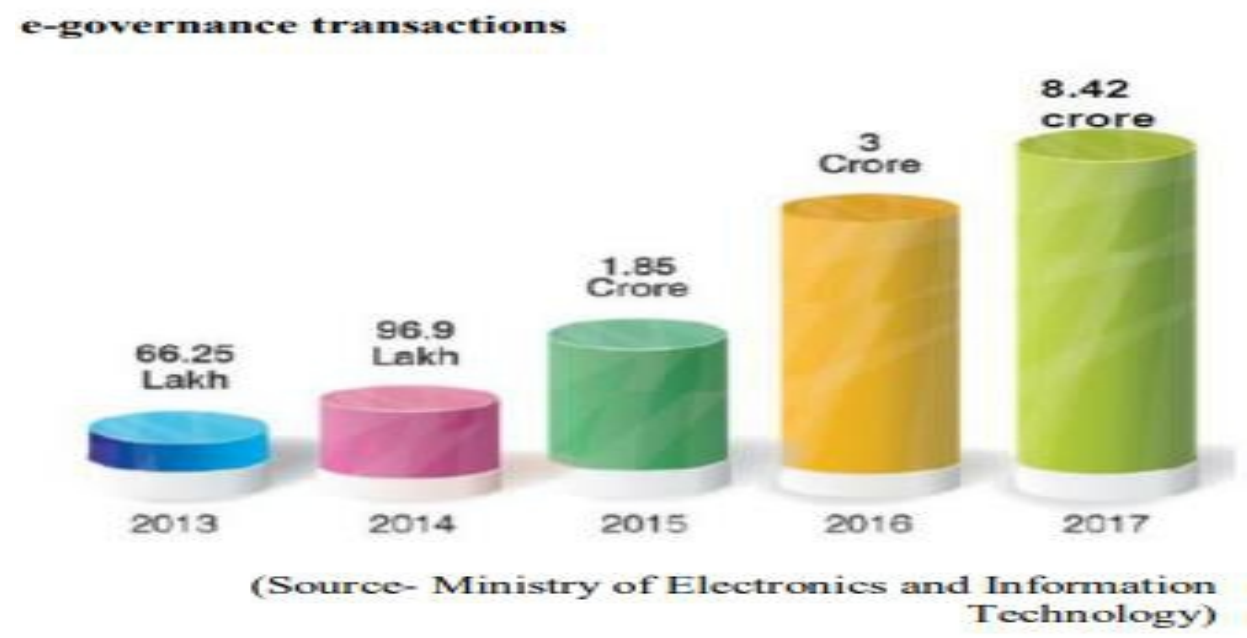

Internet penetration and mobile connectivity have made it possible for citizens to have access to government information via my.gov.in and the volume of e-governance transactions has increased manifold as can be seen by the above figure. It is, therefore, time to ride the wave of Technology for education sector too.

\section{ICT in the Education sector}

India, like any other knowledge economy, depends upon the educational sector (Hatangadi and Ghosh 2008). The demand for education in India has skyrocketed as education is still regarded as an important bridge of social, economic and political mobility (Amutabi and Oketch, 2003 as cited in Mukhopadhyay and Parmar, 2014). To cater to this demand, one of the mission of the National E-Governance Plan (NeGP) is to focus on Education sector and provide greater access to higher education with equity, especially to vulnerable groups, using the latest technology available. With digital technologies now acting as enablers, the 'iron triangle' of access, quality and cost can be achieved. Online learning and OER (Open Education Resources) movement are the game changers for higher education. (Hill and Lawton 2018). Its aim is to widen access and participation to everyone by removing barriers and making learning accessible, abundant, and customisable for all by using digital technologies (Santos et al, 2016). Through open education, each and every individual, at every stage in their lives and career development, can have appropriate and meaningful educational opportunities available to them. These include access to content, courses, support, assessment and certification 
in ways that are flexible and accommodate diverse needs. Barriers, for example, those related to entry and cost, are reduced or eliminated. Opening up education is important for universities for various reasons. Besides being a policy priority, it works as a catalyst for teaching and learning innovation via digital technologies. In spite of the focus on digital technologies in India, online learning remains supplementary for most institutions (Garett 2017) Universities should both improve their digital competencies to participate fully and it must be supported by an integrated and reliable infrastructure, linked to appropriate and relevant skills on part of educators too.

Under ICT-based learning tools for effective teaching-learning process, the following initiatives have been taken by the Government of India.

The National Mission on Education through ICT Scheme (NMEICT): It aims to leverage the potential of ICT for teaching and learning processes. The Mission has two major components - content generation and providing connectivity along with provision for access devices to the institutions and the learners. Under the NMEICT Mission connectivity to 419 Universities/ University level Institutions and 25000+ colleges and polytechnics in the country has been provided. (MHRD website, Government of India )

E-PG PATHSHALA: Approximately 23,500 modules in 70 subjects and 723 papers are developed in a four-quadrant approach of e-PG Pathshala Project (https://epgp.inflibnet.ac.in/). Approximately 41 lakhs learners across the globe have accessed e-PG Pathshala.

MOOCS ON SWAYAM PORTAL: These are the online courses on the pattern of Coursera and Edex. The government has launched SWAYAM (Study Web of Active and Young Aspiring Minds) portal that provides an integrated platform for online courses, using information and communication technology (ICT). Through this, any student can join virtual courses offered by the best teachers in the country, interact with the teacher, take tests, earn academic credits and transfer them on their academic record.

Annual Refresher Programme in Teaching (ARPIT) is a unique initiative of online professional development of in-service teachers of higher education using MOOCs platform SWAYAM. It was launched by MHRD on the 13th of November, 2018. ARPIT is a 40-hour programme with 20 hours of video content offered in a highly flexible format which can be done at one's own pace and time. On completion of the course, the teachers will be suitably credited with credits for career advancement, as decided by UGC, the regulatory body on accreditation.

NAD In 2017, NAD was launched as an online storehouse of academic awards (degrees, diplomas, certificates, mark sheets etc.) lodged by the academic institutions/boards/eligibility assessment bodies in a digital format. The NAD website helps in validating their authenticity, their safe storage and 
easy retrieval. This has eliminated the need for the students to approach the institutions in person thus helping to save resources, including time and effort on the part of students as well as the educational Institutions.

With the implementation of all these initiative, it can be rightly concluded that India's higher education landscape is all set to change for the better. However, these initiatives can be successful only if the HEIs are prepared to embrace technology. Successful implementation of ICT depends more on people and processes. It also depends upon influencing, empowering teachers, supporting them in their engagement with the students in learning rather than acquiring computer skills, and obtaining software and equipment.

\section{Use of ICT in Educational Administration}

This thrust on digital literacy in India can be used extensively in the field of educational administration too. There is a need for the Universities to incorporate ICT in four major areas under administrative management, namely financial management, management of infrastructure and office management including management of records and communications. Adoption of ICT in higher education in India needs further exploration (Rosaline and Wesley, 2017). Nevertheless, there are examples of adoption of ICT by Indian universities from the private and public sector. One such case of Lovely Professional University from the private sector has been cited above. Besides, IGNOU, a public sector open university, uses the online system, beginning with admission notification on the website, calls for online application, processing, fee transaction and even the confirmation of admission. All such services help the university increase transparency and accountability (Mukhopadhyay and Parmar, 2014). It is evident that administrative functions such as student registration, grades, course schedules and even staffing evaluation have benefitted from the use of ICT. The conclusion is that the Integration of ICT in Higher Education is inevitable (UNESCO, 2009)

HEIs are tapping the digital medium to develop robust websites showcasing their respective institutions, using social media to engage with the student and the medium of advertising to attract students and increase visibility. However, ICT application is neither uniform across all higher education institutions nor across various areas of administration and management.

\section{Objectives of the Study}

As discussed above, the use of ICT exists in Universities but in bits and pieces and become islands of information. There is a need to integrate the computerisation of educational institution into a unified system, making the process uncomplicated and transparent. 
The main objective of this study is to apply the European Framework for digitally competent Educational Organisations to the selected Universities in order to evaluate the process of implementation of ICT in its various aspects and its efficacy as an integrated system. This framework will form the basis for the formulation of the questionnaire that will seek to answer the following research questions:-

1. Is the European Digcomp framework suitable to measure eGovernance in HEIs in India?

2. What is the status of e-governance infrastructure in various types of Educational Institutions in the capital city of India?

3. What are the challenges in implementations of e-governance in these HEIs?

4. What are the critical success factors of e-governance in HEIs?

\section{The European DigCompOrg Framework}

The European DigCompOrg Framework assesses the readiness and competence of HEIs on vital parameters of leadership and governance, teaching \& learning practices, Professional Development and practices, assessment procedures, degree of collaboration \& networking and availability of infrastructure and its maintenance.

Tables 1 to 6 given below describe the framework in a concise easy to comprehend form:

\section{Table 1}

Leadership and governance Practices: The first parameter is the role of leadership of the university. The vision and mission should include encompassing digital technologies to modernize the University. The benefits of digital technology are communicated to all and roles clearly assigned

\begin{tabular}{|c|c|c|}
\hline $\begin{array}{l}\text { Thematic } \\
\text { elements }\end{array}$ & Sub-elements & Descriptors \\
\hline \multirow{9}{*}{$\begin{array}{l}\text { Leadership \& } \\
\text { Governance } \\
\text { Practices }\end{array}$} & \multirow{4}{*}{$\begin{array}{l}\text { Integration of } \\
\text { Digital-age Learning } \\
\text { is part of the overall } \\
\text { mission, vision and } \\
\text { strategy }\end{array}$} & $\begin{array}{l}\text { 1. The potential of digital learning technologies is } \\
\text { clearly flagged }\end{array}$ \\
\hline & & $\begin{array}{l}\text { 2. The benefits of digital learning technologies are } \\
\text { communicated }\end{array}$ \\
\hline & & $\begin{array}{l}\text { 3. The strategic plan encompasses digital-age } \\
\text { learning }\end{array}$ \\
\hline & & 4. Open education is an aspect of public engagement \\
\hline & \multirow{5}{*}{$\begin{array}{l}\text { Strategy for digital- } \\
\text { age learning is } \\
\text { supported by an } \\
\text { implementation plan }\end{array}$} & $\begin{array}{l}\text { 5. Planning builds on enablers while addressing } \\
\text { barriers }\end{array}$ \\
\hline & & 6. Internal stakeholders have a degree of autonomy \\
\hline & & $\begin{array}{l}\text { 7. Opportunities, incentives and rewards for staff are } \\
\text { identified }\end{array}$ \\
\hline & & $\begin{array}{l}\text { 8. Digital-age learning is aligned with broader } \\
\text { priorities }\end{array}$ \\
\hline & & $\begin{array}{l}\text { 9. There are twin goals of modernising existing } \\
\text { educational provision and offering new opportunities }\end{array}$ \\
\hline & \multirow{7}{*}{$\begin{array}{l}\text { A Management and } \\
\text { Governance Model is } \\
\text { in place }\end{array}$} & $\begin{array}{l}\text { 10. There is a shared understanding of and } \\
\text { commitment to the implementation plan }\end{array}$ \\
\hline & & 11. Management responsibility is clearly assigned \\
\hline & & 12. Resources are aligned with budgets and staffing \\
\hline & & $\begin{array}{l}\text { 13. The outcomes, quality and impact of the } \\
\text { implementation plan are reviewed }\end{array}$ \\
\hline & & 14. Specific initiatives or pilots are evaluated \\
\hline & & 15. Implementation status is benchmarked \\
\hline & & 16. Oversight of policy and direction is evident \\
\hline
\end{tabular}




\section{(Source: Digicomp Framework \\ publications.jrc.ec.europa.eu/repository/bitstream/JRC98209/jrc98209_r_digcomporg_ \\ final.pdf)}

Table 2

Teaching and Learning: The framework examines the extent to which the University promotes Digital Competence among staff and students. The process includes assessing creativity, social and emotional skills of the teachers and students and building collaborations with all the stakeholders in the process.

\begin{tabular}{|c|c|c|}
\hline \multirow{12}{*}{$\begin{array}{l}\text { Teaching and } \\
\text { Learning } \\
\text { Practices }\end{array}$} & \multirow{4}{*}{$\begin{array}{l}\text { Digital Competence } \\
\text { is promoted, } \\
\text { benchmarked and } \\
\text { assessed }\end{array}$} & 17. Staff and students are Digitally-Competent \\
\hline & & $\begin{array}{l}\text { 18. Safety, risks and responsible behaviour in online } \\
\text { environments are foregrounded }\end{array}$ \\
\hline & & $\begin{array}{l}\text { 19. The Digital Competence (DC) of staff and } \\
\text { students is benchmarked }\end{array}$ \\
\hline & & 20. DC is included in staff appraisal \\
\hline & \multirow{8}{*}{$\begin{array}{l}\text { A rethinking of roles } \\
\text { and pedagogical } \\
\text { approaches takes } \\
\text { place }\end{array}$} & 21. Staff are partners in change \\
\hline & & 22. New roles are envisaged for staff \\
\hline & & 23. New roles are envisaged for students \\
\hline & & 24. Pedagogical approaches are expanded \\
\hline & & 25. Personalised learning is developed \\
\hline & & 26. Creativity is promoted \\
\hline & & 27. Collaboration and group work is expected \\
\hline & & 28. Social and emotional skills are developed \\
\hline
\end{tabular}

(Source: Digicomp Framework

(publications.jrc.ec.europa.eu/repository/bitstream/JRC98209/jrc98209_r_digcomporg

_final.pdf)

Table 3

Professional Developments: the continuing professional development of teachers is a requirement for relevant and high-quality digital-age learning. Strong support for teachers to use (among other things) innovative pedagogies and digital technologies in an optimal manner is also one of the six new priority areas.

\begin{tabular}{|c|c|c|}
\hline \multirow{5}{*}{$\begin{array}{l}\text { Professional } \\
\text { Development }\end{array}$} & \multirow{5}{*}{-} & $\begin{array}{l}\text { 29. A commitment to Continuous Professional } \\
\text { Development (CPD) is evident }\end{array}$ \\
\hline & & 30. CPD is provided for staff at all levels \\
\hline & & $\begin{array}{l}\text { 31. CPD is aligned with individual and organisational } \\
\text { needs }\end{array}$ \\
\hline & & 32. A wide range of CPD approaches is evident \\
\hline & & $\begin{array}{l}\text { 33. Accredited/certified CPD opportunities are } \\
\text { promoted }\end{array}$ \\
\hline
\end{tabular}

(Source: Digicomp Framework

(publications.jrc.ec.europa.eu/repository/bitstream/JRC98209/jrc98209_r_digcomporg

_final.pdf) 


\section{Table 4}

Assessment Practices: The no of students in some of the Indian Higher Education Institutes is huge. This element refers to the role that digital technologies play in student assessment giving all stakeholders timely and meaningful information on student's experiences and achievements.

\begin{tabular}{|c|c|c|}
\hline \multirow{9}{*}{$\begin{array}{l}\text { Assessment } \\
\text { practices }\end{array}$} & \multirow{4}{*}{$\begin{array}{l}\text { Assessment } \\
\text { Formats are } \\
\text { engaging and } \\
\text { motivating }\end{array}$} & 4. The scope of formative assessment is ex \\
\hline & & 35. Summative assessment is diversified \\
\hline & & 36. Self- and peer-assessment are promoted \\
\hline & & $\begin{array}{l}\text { 37. Rich, personalised and meaningful feedback is } \\
\text { encouraged and expected }\end{array}$ \\
\hline & $\begin{array}{l}\text { Informal and Non- } \\
\text { Eormal Learning are } \\
\text { recognised }\end{array}$ & $\begin{array}{l}\text { 38. Prior, experiential and open learning are } \\
\text { recognised and accredited }\end{array}$ \\
\hline & \multirow{4}{*}{$\begin{array}{l}\text { Learning Design is } \\
\text { Informed by } \\
\text { Analytics }\end{array}$} & 39. Learning analytics is given strategic consideration \\
\hline & & 40. A code of practice for learning analytics is in place \\
\hline & & 41. Learning is supported through learning analytics \\
\hline & & $\begin{array}{l}\text { 42. Quality management and curriculum/programme } \\
\text { design are supported through learning analytics }\end{array}$ \\
\hline
\end{tabular}

(Source: Digicomp Framework

(publications.jrc.ec.europa.eu/repository/bitstream/JRC98209/jrc98209_r_digcomporg

$$
\text { _final.pdf) }
$$

\section{Table 5}

Collaboration and Networking: This parameter is required to assess whether the Higher Education Institute supports a culture of collaboration and communication and has processes and policies in place to enable staff and students to engage with internal and external stakeholders, share experiences and learn effectively within and beyond the organisational boundaries.

\begin{tabular}{|c|c|c|}
\hline \multirow{9}{*}{$\begin{array}{l}\text { Collaboration } \\
\text { and } \\
\text { Networking }\end{array}$} & \multirow{5}{*}{$\begin{array}{l}\text { Networking, sharing } \\
\& \text { collaboration is } \\
\text { promoted }\end{array}$} & $\begin{array}{l}\text { 54. Networked collaboration for staff to pool } \\
\text { expertise and share contents is the norm }\end{array}$ \\
\hline & & 55. Knowledge exchange efforts are recognised \\
\hline & & 56. Students engage in effective networking \\
\hline & & $\begin{array}{l}\text { 57. Participation in knowledge-exchange activities } \\
\text { and events is promoted }\end{array}$ \\
\hline & & $\begin{array}{l}\text { 58. Internal collaboration and knowledge exchange is } \\
\text { expected }\end{array}$ \\
\hline & \multirow{2}{*}{$\begin{array}{l}\text { A strategic } \\
\text { approach is taken to } \\
\text { communication }\end{array}$} & 59. An explicit communication strategy is in place \\
\hline & & 60. A dynamic online presence is evident \\
\hline & \multirow{2}{*}{$\begin{array}{l}\text { Partnerships are } \\
\text { developed }\end{array}$} & $\begin{array}{l}\text { 61. A commitment to knowledge exchange through } \\
\text { partnerships is evident }\end{array}$ \\
\hline & & $\begin{array}{l}\text { 62. Staff and students are incentivised to be actively } \\
\text { involved in partnerships }\end{array}$ \\
\hline
\end{tabular}

(Source: Digicomp Framework

(publications.jrc.ec.europa.eu/repository/bitstream/JRC98209/jrc98209_r_digcomporg _final.pdf) 


\section{Table 6}

Infrastructure: This parameter has a crucial role in enabling digital technologies. The HEIs should have in place effective procurement planning. An operation plan for core ICT solutions in different modules like Interactive Web Portal, Student Information System (including their Registration, Attendance, Examination etc.), Library Information System, Accounts, Payroll, Inventory System, Transport etc. The complete breakdown structure may differ depending on the size of the University. It is also important here that IT infrastructure should be such that it is taken into account the future expansion, if any, being considered by the University.

\begin{tabular}{|c|c|c|}
\hline \multirow{12}{*}{ Infrastructure } & \multirow{2}{*}{$\begin{array}{l}\text { Physical and Virtual } \\
\text { Learning Spaces are } \\
\text { designed for digital- } \\
\text { age learning }\end{array}$} & $\begin{array}{l}\text { 63. Physical learning spaces optimise the affordances } \\
\text { of digital-age learning }\end{array}$ \\
\hline & & 64. Virtual Learning Spaces are optimised \\
\hline & \multirow{10}{*}{$\begin{array}{l}\text { The digital } \\
\text { infrastructure is } \\
\text { planned and } \\
\text { managed }\end{array}$} & 65. An Acceptable Usage Policy is in place \\
\hline & & $\begin{array}{l}\text { 66. Pedagogical and technical expertise direct } \\
\text { investments in digital technologies }\end{array}$ \\
\hline & & $\begin{array}{l}\text { 67. A range of digital learning technologies supports } \\
\text { anytime/anyplace learning }\end{array}$ \\
\hline & & $\begin{array}{l}\text { 68. Bring Your Own Device (BYOD) approaches are } \\
\text { supported }\end{array}$ \\
\hline & & $\begin{array}{l}\text { 69. Risks relating to inequality and digital inclusion } \\
\text { are addressed }\end{array}$ \\
\hline & & 70. Technical and user support is evident \\
\hline & & 71. Assistive technologies address special needs \\
\hline & & $\begin{array}{l}\text { 72. Measures to protect privacy, confidentiality and } \\
\text { safety are well established }\end{array}$ \\
\hline & & 73. Effective procurement planning is evident \\
\hline & & $\begin{array}{l}\text { 74. An operational plan for core ICT backbone and } \\
\text { services is in place }\end{array}$ \\
\hline
\end{tabular}

(Source: Digicomp Framework

(publications.jrc.ec.europa.eu/repository/bitstream/JRC98209/jrc98209_r_digcomporg _final.pdf)

Based on this framework a questionnaire has been prepared to assess the selected Higher Educational Institutes (HEIs), which has been appended as Appendix- I.

Academic Literature points to the relevance of these parameters in the Indian context. For instance, a study on e-governance initiatives in the Indian state of Maharashtra points to a huge lack of people with relevant qualifications and experience to implement and man e-governance projects in the state (Kumarwad \& Kumbhar, 2016). Paucity of people with relevant technical skills apart, a lack of adequate ICT infrastructure is a constant challenge in developing countries ((Light et al., 2009), India being no exception, with a survey on UGC accredited HEIs revealing several shortcomings in IT infrastructure, particularly in those from the rural areas (Pegu, 2014). The non-availability of content in electronic form is another shortcoming, further exacerbated by the fact that there are 22 officially recognised languages in the country, which renders it extremely challenging to provide a standardised study material Pegu, 2014). The HEIs will be examined on all the parameters of the European DigCompOrg Framework described above. 


\section{Expected Results}

As mentioned in a previous section, one of the main objectives of the survey is to assess the extent to which the HEIs have incorporated ICT in various aspects of administration and management. In addition, it will help the HEIs to examine their level of competence to implement ICT in all its aspects. The given framework assesses the status of ICT integration on the 6 parameters - namely - Leadership and Governance Practices, Teaching and Learning Practices, Professional Development of the Teaching and NonTeaching staff, Assessment Practices, Collaboration and Networking; and Infrastructure. The following results are expected out of administering the questionnaire to the target groups as specified in the section on methodology:

i) Top Management support and the degree of functional autonomy of digitisation administrators and the necessary budgetary backing are important factors that determine the level of success in the implementation of ICT in HEIs.

ii) An emphasis on ICT in plans and strategies, providing appropriate communication to all the stakeholders, adequate training and incentives (monetary and non-monetary) to the faculty and staff has a favourable effect on successful implementation.

iii) Technological infrastructure, as well as making its proper use and ensuring Collaboration and Networking between the learners and the providers has an important role to play in both, smooth implementation of, as well as maximising the benefits from, ICT.

iv) Besides infrastructure, faculty and staff training and motivation and adoption of newer methods of learning by the students are the major challenges in the successful implementation of ICT in HEIs.

\section{Difficulty expected during the study}

The University system caters to varied stakeholders and therefore measuring e-governance in Universities can be difficult. E-governance is not about ICT hardware or software tools but applicability or its success depends upon the people and processes. The level of response of employees of the Universities- faculty, staff, students, administrators, trustees etc to come out with honest answers could be the impediments to the study. There is also a lack of clarity on the use and practice of OER and MOOCs.

\section{Conclusion}

Relative advantages of technology, namely accuracy, cost saving have encouraged HEIs to embrace ICT in all its administrative management functions. Institutions are also trying to be digitally competent to supplement education through OER and MOOCs. Especially so when there is a lot of 
impetus from the Government of India to digitise India and to encourage HEIs to adopt digital technologies. To participate fully with the mission of Digital India, HEIs must be supported by motivated educators and students with relevant skills. This paper has adopted the European Digicom framework to assess the integration of ICT in HEIs based on the six parameters, namely Leadership and Governance Practices, Teaching and Learning Practices, Professional Development of the Teaching and Non-Teaching staff, Assessment Practices, Collaboration and Networking; and Infrastructure. A questionnaire has been formulated for the University's administrators, the faculty and the students to measure the extent of digital competence. It is expected that Top Management support, functional autonomy, adequate training and motivation for the staff and students, budgetary support and infrastructural facilities will emerge as some of the important factors in determining success in the implementation of ICT in the HEIs in India.

\section{References:}

1. Amutabi, M. N., \& Oketch, M. O. (2003). 'Experimenting in distance education: the African Virtual University (AVU) and the paradox of the World Bank in Kenya'. International Journal of Educational Development, 23(1), 57-73.

2. Christopher, H., \& William, L. (2018). Universities, the digital divide and global inequality. Journal of Higher Education Policy and Management, 40(6), 598-610, DOI: 10.1080/1360080X.2018.1531211

3. E-Pathshala The online Education portal Information. Retrieved from http://www.epaathshaala.org/

4. Garett, R. (2017) Whatever happened to online learning? Retrieved from http://dx.doi.org/10.6017/ihe.2019.97.10935

5. Hattangdi, A., \& Ghosh, A. (2008). Enhancing the quality and accessibility of higher education through the use of Information and Communication Technologies. In International Conference on Emergent Missions, Resources, and the Geographic Locus in Strategy as a part of the 11th Annual Convention of the Strategic Management Forum (SMF), India 2008 (Vol. 2011, pp. 1-14, Vol. 28 March).

6. Inamorato dos Santos, A., Punie, Y., \& Castaño-Muñoz, J. (2016) Opening up Education: A Support Framework for Higher Education Institutions. JRC Science for Policy Report, EUR 27938 EN; doi:10.2791/293408

7. Jain, V. K., and. Ramani, A. K. (2005). Concepts and applications of e-governance: Illustrations through some case studies. Journal of the Eighth National Conference on E-Governance, 65-71. 
8. Kampylis, P., Punie, Y., \& Devine, J. (2015). Promoting Effective Digital-Age Learning - A European Framework for DigitallyCompetent Educational Organisations. EUR 27599 EN; doi:10.2791/54070

9. Kumarwad, L. L., \& Kumbhar, R. D. (2016). E-Governance Initiatives in Maharashtra (India): Problems and Challenges I.J. Information Engineering and Electronic Business. 5, 18-25

10. Light, D., Culp, K. M., Menon, R., \& Shulman, S. (2006). Intel ® teach to the future essentials course *: Impact survey results for 2005 (pp. 150). Retrieved fromhttp://download.intel.com/

11. Lovely Professional University. Retrieved from https://www.lpu.in/student_services/ums.php

12. Mukhopadhyay, M., \& Parhar, M. (2014). ICT in Indian Higher Education Administration and Management. In Huang R., Kinshuk, Price J. (eds), ICT in Education in Global Context: Lecture Notes in Educational Technology. Springer, Berlin, Heidelberg.

13. Pegu, U. K. (2014). Information and Communication Technology in Higher Education in India: Challenges and Opportunities. International Journal of Information and Computation Technology. 4 (5), 513-518

14. Rosaline, S., \& Wesley, J. R. (2017). Factors Affecting Students' Adoption of ICT Tools in Higher Education Institutions: An Indian Context. International Journal of Information and Communication Technology Education (IJICTE), 13(2), 82-94.

15. National Mission on education through ICT. Retrieved from [https://mhrd.gov.in/technology-enabled-learning-]

16. Swayam: The Government of India portal for free online education Information. Retrieved from [https://swayam.gov.in/About]

17. Vijayan, A. (2009). Digital India - A Roadmap to Sustainability. International Journal of Innovative Technology and Exploring Engineering (IJITEE), 8(5), 571-576. 